\title{
BEZPIECZEŃSTWO DEPOZYTÓW W ŚWIETLE ISLANDZKICH I CYPRYJSKICH DOŚWIADCZEŃ KRYZYSU FINANSOWEGO - ASPEKTY REGULACYJNE
}

\section{WPROWADZENIE}

Utworzenie powszechnego ubezpieczenia depozytów w USA w 1933 r. w postaci Federal Deposit Insurance Corporation (FDIC) było posunięciem budzącym kontrowersje. Przełom w dyskusji nad zasadnościa gwarantowania depozytów nastapił w drugiej połowie XX w. ${ }^{1}$ Współcześnie bezpieczeństwo depozytów stanowi jeden z wyznaczników stabilnego systemu finansowego, a gwarantowanie depozytów jest jednym z szeregu instrumentów oddziaływania państwa na sektor bankowy. Poniższy artykuł ma na celu zaprezentowanie problematyki bezpieczeństwa depozytów w ramach prowadzonych działań restrukturyzacyjnych banków. W tym celu odwołano się przede wszystkim do doświadczeń Islandii i Cypru. Co istotne, w obu przypadkach sięgnięto po depozyty jako jedno ze źródeł finansowania prowadzonych działań naprawczych. Analizie poddane zostały również kluczowe aspekty pokryzysowej reformy gwarantowania depozytów w celu określenia granic ingerencji w prawa deponentów na podstawie nowych ram prawnych.

\section{PROBLEMATYKA REGULACYJNA}

Z teoretycznego punktu widzenia gwarantowanie depozytów należy umieszczać w ramach szerszego celu regulacji działalności bankowej, jakim są bezpieczeństwo i ochrona klienta. Choć współcześnie obejmuje on szeroki zakres działań dotyczących relacji bank-klient, to pierwotnie odnosił się przede wszystkim do bezpieczeństwa deponentów. Utworzenie pierwszej instytucji gwarantującej depozyty zgromadzone w bankach w postaci FDIC stanowiło bezpośrednią odpowiedź na wielki kryzys. Jej głównym celem było odbudowanie zaufania społecznego wobec sektora bankowego, które zostało poważnie

\footnotetext{
1 Jak wskazuja M. Friedman i A. Schwartz, system gwarantowania depozytów był najważniejszą zmianą strukturalną w amerykańskim systemie bankowym, wynikającą z kryzysu 1933 r., która w znaczący sposób wpływała na osiagnięcie stabilności monetarnej. M. Friedman, A. J. Schwartz, A Monetary History of the United States, 1867-1960, Princeton 2008, s. 434.
} 
nadwątlone serią bankructw banków w latach 1929-1933². To z kolei miało zapobiegać gwałtownemu wycofywaniu depozytów bankowych. Powstanie FDIC dało początek nowemu podejściu do kwestii zapewnienia stabilności sektora bankowego nie tylko w USA, lecz także na całym świecie.

Współcześnie główny ciężar dyskusji naukowej został przesunięty z zasadności powołania systemu gwarantowania depozytów na jego efektywność, tj. na zagadnienie uwarunkowań instytucjonalnych eliminujacych problemy wynikających z jego wprowadzenia ${ }^{3}$. W zależności od zakresu działań przypisanych systemom gwarantowania depozytów przez ustawodawców systemy gwarantowania można podzielić na cztery typy, tj. od podstawowego modelu pay-box opartego na podstawowej funkcji, jaka jest wypłata depozytów gwarantowanych, przez tzw. pay-box-plus, do zaawansowanych modeli typu loss-minimizer czy risk-minimizer, które uwzględniają zadania z zakresu ograniczania ryzyka w systemie bankowym, z pakietem instrumentów wczesnej interwencji oraz narzędzi przymusowej restrukturyzacji i likwidacji problemowego banku ${ }^{4}$.

Jak wskazuja Remigiusz Kaszubski oraz Agata Tupaj-Cholewa, obecnie jednym z generalnych celów działalności państwa w obszarze działalności bankowej jest zapewnienie bezpieczeństwa środków pochodzących od ludności, a gromadzonych w systemie finansowym. Sam ten cel oddaje ideę ingerencji państwa w gospodarkę - ma ono chronić słabszych (ekonomicznie) uczestników rynku oraz wyrównywać szanse przez zapewnienie równego dostępu do informacji czy poszczególnych produktów finansowych. Jednakże w żadnym wypadku celem państwa nie powinno być eliminowanie ryzyka $\mathrm{z}$ działalności finansowej, natomiast państwo powinno przeciwdziałać przerzucaniu tego ryzyka przez banki na deponentów. Przy takim podejściu bezpieczeństwo banku to bezpieczeństwo środków zgromadzonych na rachunkach bankowych oraz bezpieczeństwo wszystkich klientów korzystających z usług bankowych ${ }^{5}$.

Zgodnie z powyższym współcześnie systemy gwarantowania depozytów stały się nieodzownym elementem sieci bezpieczeństwa rozwiniętego systemu finansowego, będacc standardem rekomendowanym przez instytucje międzynarodowe. W 2009 r. Bazylejski Komitet ds. Nadzoru Bankowego oraz Międzynarodowe Stowarzyszenie Ubezpieczycieli Depozytów (IADI) opracowały

${ }^{2} \mathrm{~W}$ czteroletnim okresie poprzedzającym powstanie FDIC upadło ponad 9000 banków, co stanowiło jedną trzecią wówczas działających podmiotów. B. Zdanowicz, Amerykański sposób restrukturyzacji banków - doświadczenia Federal Deposit Insurance Corporation (FDIC), „Bezpieczny Bank” 2014, nr 1(54), s. 9.

${ }^{3}$ Szerzej zob. A. Demirguc-Kunt, E. Detragiache, Does deposit insurance increase banking system stability? An empirical investigation, „Journal of Monetary Economics” 49(7), 2002, s. 13731406; A. Pawlikowski, Optymalny model gwarantowania depozytów, „Bezpieczny Bank” 2010, nr 3(42), s. 101-115; B. Zdanowicz, Podstawowe dylematy i kryteria wyboru formuty systemu gwarantowania depozytów w świetle teorii i doświadczeń międzynarodowych, „Bezpieczny Bank” 2007, nr 1(34), s. 3-231.

4 J. Pruski, J. Szambelańczyk, Systemy gwarantowania depozytów w sieciach bezpieczeństwa finansowego na tle konsekwencji globalnego kryzysu finansowego, „Bezpieczny Bank” 2014, nr 4(57), s. 106-107.

${ }_{5}$ R. Kaszubski, A. Tupaj-Cholewa, Prawo bankowe, Warszawa 2010, s. 166. 
dokument „Główne zasady efektywnego systemu gwarancji depozytów”6. Natomiast Międzynarodowy Fundusz Walutowy (MFW), Bank Światowy, Komisja Europejska (KE) oraz Europejskie Forum Ubezpieczycieli Depozytów wydały w grudniu 2010 r. zarys metodologii oceny zgodności z powyższymi zasadami. W lutym 2011 r. Rada Stabilności Finansowej (ang. Financial Stability Board - FSB) zgodziła się na włączenie ich do zasad stabilnego systemu finansowego. Również MFW oraz Bank Światowy dołączyły przedmiotowe zasady do kryterium oceny poszczególnych państw w ramach badania Reports on Observance of Standards and Codes. W latach 1974-2003 liczba oficjalnych systemów gwarantowania depozytów wzrosła z 12 do $88^{7}$. Obecnie IADI zrzesza 79 systemów gwarancyjnych, jednocześnie informując o zidentyfikowanych 113 systemach gwarancyjnych ${ }^{8}$.

Znaczenia gwarancji depozytów potwierdzają również działania antykryzysowe, które często w pierwszej kolejności dotyczą gwarantowania depozytów. Przykładowo w przypadku banku Northern Rock, gdy 14 września 2007 r. zrealizowało się ryzyko gwałtownej wypłaty depozytów, już 17 września podjęto decyzję o wprowadzeniu pełnych gwarancji depozytów w tym banku. Podobnie po upadku banku Lehman Brothers wprowadzono podwyższony limit gwarancji z 100 tys. dolarów do kwoty 250 tys. dolarów (na okres od października 2008 r. do końca grudnia 2009 r.) ${ }^{9}$. W sumie z grupy państw wchodzących w skład FSB dziesięć z nich podwyższyło limit gwarantowania, przy czym aż cztery wprowadziły pełne gwarancje (Niemcy, Francja, Singapur i Hongkong) ${ }^{10}$. Nieskoordynowane zwiększanie poziomu gwarancji miało również miejsce w innych państwach UE (m.in. Austria, Belgia, Portugalia, Hiszpania). Oznaczało to zakłócenie zasad jednolitego rynku oraz generowało przepływy depozytów między krajami o różnym poziomie gwarancji. Stało się to bezpośrednią przyczyną rozpoczęcia prac nad nowelizacją dyrektywy 94/19/WE w sprawie systemów gwarancji depozytów ${ }^{11}$. Jedną z podjętych zmian było podniesienie limitu gwarancji najpierw z 20 tys. do 50 tys. euro (czerwiec 2009 r.), a następnie do zharmonizowanego poziomu 100 tys. euro (od 2011 r.) $)^{12}$.

Kryzys finansowy unaocznił złożoność problematyki gwarantowania depozytów w sytuacji funkcjonowania jednolitego rynku usług bankowych w UE.

${ }^{6}$ Core Principles for Effective Deposit Insurance Systems, Basel Committee on Banking Supervision, International Association of Deposit Insurers, 2009, http://www.bis.org/publ/bcbs156. pdf [dostęp: 12.06.2015].

${ }^{7}$ A. Demirguc-Kunt, B. Karacaovali, L. Laeven, Deposit insurance around the world: a comprehensive database, Policy Research Working Paper Series, The World Bank 2005, s. 3.

${ }^{8}$ Zgodnie z informacjami zamieszczonymi na stronach IADI http://www.iadi.org/aboutIADI. aspx?id=48, http://www.iadi.org/di.aspx?id=67 [dostęp: 12.06.2015].

${ }^{9}$ H. Ngalawa, F. Tchana Tchana, N. Viegi, Banking Instability and Deposit Insurance: The Role of Moral Hazard, MPRA Paper, University Library of Munich 2011, s. 4.

${ }^{10}$ Thematic Review on Deposit Insurance Systems. Peer Review Report, Financial Stability Board 2012, s. 10-12, http://www.financialstabilityboard.org/publications/r_120208.pdf [dostęp: 12.06.2015].

${ }^{11}$ Dyrektywa Parlamentu Europejskiego i Rady 94/19/WE z 30 maja 1994 r. w sprawie systemów gwarancji depozytów, Dz. Urz. WE L 135 z 31 maja 1994 r., s. 5.

${ }^{12}$ E. Terták, K. Szelag, The Financial Crisis and the Reform of Deposit Guarantee Schemes in the EU, „Bezpieczny Bank” 2010, nr 2(41), s. 106 i 109. 
Z perspektywy czasu, mimo że udało się opanować główne zaburzenia, to jednak obnażone zostały niedoskonałości głównie w obszarze finansowania oraz współpracy transgranicznej. Odpowiedzialność z tytułu gwarantowania depozytów wraz z niedostatecznym wyposażeniem finansowym instytucji gwarantujących w dużym stopniu miała wpływ na rozwój kryzysu, w tym w szczególności przez powiązanie między kondycją sektora bankowego a stanem finansów publicznych. Niewystarczająca (np. Irlandia) czy też wątpliwa (Włochy, Hiszpania) zdolność krajowych budżetów do absorpcji strat sektora bankowego stała się przyczyną kryzysu finansów publicznych, co w konsekwencji musiało oznaczać niechęć do partycypowania w kosztach działań restrukturyzacyjnych transgranicznych instytucji bankowych (np. przypadek banku Dexia). Kluczowe w tym obszarze okazały się dwa założenia przedkryzysowej, unijnej architektury regulacyjnej w zakresie działalności bankowej, tj. pozostawienie nadzoru nad oddziałami banków oraz gwarantowania depozytów ${ }^{13}$ w kompetencji organów państw macierzystych, przy czym jednocześnie szeroko rozumiane gospodarcze skutki upadku danego podmiotu bankowego pozostawały w żywotnym interesie kraju goszczącego ${ }^{14}$.

\section{ISLANDIA I CYPR - WYBRANE DOŚWIADCZENIA}

W przypadku szczególnie dramatycznego załamania systemu bankowego, jakie wystapiło w Islandii i na Cyprze, w ocenie organów decyzyjnych konieczne okazało się sięgnięcie po środki zgromadzone w bankach. Z perspektywy deponenta warto prześledzić schemat prowadzonych działań, a przede wszystkim ich ocenę prawną dokonaną zarówno przez sądy krajowe, jak i właściwe organy w ramach Europejskiego Obszaru Gospodarczego (EOG).

\section{Islandia - zarys działań antykryzysowych i kluczowe orzeczenia krajowe oraz Trybunału EFTA}

Sytuacja trzech największych islandzkich banków - Kaupthing Bank, Landsbanki Íslands hf., Glitnir Bank - stanowiących ok. 85\% aktywów sektora bankowego (ponad 900\% islandzkiego PKB) ${ }^{15}$ uległa gwałtownemu pogorszeniu na przełomie września i października 2008 r. Stojąc w obliczu załamania gospodarczego, władze Islandii zdecydowały się na podjęcie zdecydowanych kroków. Poniżej przedstawione zostaną działania podjęte w sto-

${ }^{13}$ Dodatkowo ogólny i kierunkowy charakter dyrektywy 94/19/WE nie zapobiegł znaczącemu zróżnicowaniu poszczególnych, krajowych systemów gwarancji depozytów zarówno pod względem formalnej konstrukcji, jak i praktycznej skuteczności działania.

${ }^{14}$ Szerzej zob. J. Pruski, J. Szambelańczyk, op. cit., s. 103-108; P. Smaga, Paneuropejski system gwarantowania depozytów - część I (wnioski z kryzysu), „Bezpieczny Bank” 2013, nr 2-3(5152); idem, Powiazania między sektorem bankowym a kryzysem zadtużeniowym $w$ strefie euro, „Bezpieczny Bank” 2012, nr 3(48), s. 12-24.

${ }^{15}$ Banking Crisis: The Impact of the Failure of the Icelandic Banks. The Fifth Report of the Session 2008-2009, House of Commons Treasury Committee, London 2009, s. 9. 
sunku do Landsbanki Íslands hf. (LBI), wokół którego w późniejszym okresie skupiło się szereg rozstrzygnięć prawnych.

Parlament islandzki 6 października 2008 r. przyjął ustawę nr 125/2008 (ang. Act No. 125/2008, on the Authority for Treasury Disbursements due to Unusual Financial Market Circumstances) wprowadzająca nadzwyczajne kompetencje dla władz państwowych, umożliwiające podjęcie szeregu działań przeciwdziałających kryzysowi finansowemu. W ramach przyjętej ustawy uchwalono również zmianę ustawy nr 161/2002 dotyczącej islandzkiego nadzoru finansowego (ang. Act No. 161/2002, the Financial Supervisory Authority). Islandzki nadzorca finansowy Fjármálaeftirlitid (FME) został wyposażony w szerokie kompetencje pozwalające na prowadzenie radykalnych działań mających na celu restrukturyzację upadających banków. Jednocześnie roszczeniom z tytułu depozytów nadano uprzywilejowany charakter w rozumieniu art. 112 islandzkiego prawa upadłościowego. Oznaczało to preferencyjne traktowanie deponentów pod względem kolejności zaspokajania w postępowaniu upadłościowym. Tego samego dnia internetowe strony oddziałów LBI w Wielkiej Brytanii oraz Holandii przestały działać, a deponenci utracili dostęp do swoich środków. Korzystając z nowych prerogatyw, FME 7 października 2008 r. zdecydował się na przejęcie uprawnień walnego zgromadzenia akcjonariuszy LBI oraz odwołanie jego zarządu. Powołano komitet naprawczy, który przejął wszystkie uprawnienia przynależne zarządowi LBI. Następnie na podstawie decyzji FME z 9 października 2008 r. część aktywów oraz zobowiazań banku LBI została przekazana do nowo utworzonego podmiotu Nýi Landsbanki Íslands hf., co pozostawiało część wierzycieli z roszczeniami do znaczenie uszczuplonej w ten sposób masy upadłości LBI. Analogiczne decyzje zostały podjęte w stosunku do dwóch pozostałych banków w dniach 7-9 października ${ }^{16}$.

Istotnym elementem podejmowanych działań antykryzysowych było również wdrożenie obostrzeń dotyczących przepływów kapitałowych. Nowelizacja ustawy nr 87/1992 (28 listopada 2008 r.) regulującej problematykę obrotu dewizowego umożliwiła Bankowi Centralnemu Islandii wprowadzenie zasad obrotu dewizowego nr 1082/2008 (ang. Rules on Foreign Exchange No 1082/2008), które z zastrzeżeniem katalogu szczególnych przypadków praktycznie wstrzymały wszelką wymianę dewizowa. Powodem wprowadzenia ww. regulacji były obawy władz islandzkich o kurs korony islandzkiej (ISK), a także stabilność polityki pieniężnej oraz system płatniczy kraju ${ }^{17}$.

$\mathrm{Na}$ bazie powyższego stanu faktycznego jednym z pierwszych zagadnień, jakie przyszło rozwiązać sądom islandzkim, była kwestia zgodności z konstytucją ustaw nadzwyczajnych przyjętych w październiku 2008 r. Sąd Najwyższy Islandii odniósł się do tej kwestii, rozpatrując zarzuty dotyczące zmiany

${ }^{16}$ Szerzej zob. P. S. Bafia, Kazus Icesave. Problem gwarancji depozytów gromadzonych w zagranicznych oddziałach instytucji kredytowych na podstawie sporu brytyjsko-islandzkiego, „Bezpieczny Bank” 2011, nr 2(44), s. 50-53; P. Frątczak, Definicja depozytu w świetle opinii Trybunału EFTA oraz orzeczenia Sadu Najwyższego Islandii w sprawie Aresbank S.A. przeciwko NBI hf., Fjármálaeftirlitid i rzadowi Islandii, „Bezpieczny Bank” 2013, nr 1(50), s. 36-41.

17 F. M. Baldursson, R. Portes, Capital controls and the resolution of failed cross-border banks: the case of Iceland, „Capital Markets Law Journal” 9(1), 2014, s. 43-47. 
uprzywilejowania deponentów względem pozostałych kategorii wierzycieli. Argumentacja strony powodowej w głównej mierze opierała się na naruszeniu zasady ochrony własności prywatnej, a dokładniej - wywłaszczeniu. Podnoszono również kwestie retroaktywności przepisów, niezachowania przez władze islandzkie zasady proporcjonalności środków w stosunku do zamierzonych celów, a także pośrednią dyskryminację na podstawie narodowości oraz ochronę słusznych oczekiwań. Sąd Najwyższy w wyroku z 28 października 2011 r. w sprawach 340/2011 oraz 341/2011 oddalił stawiane zarzuty, głównie opierając się na wyjątkowym charakterze okoliczności gospodarczych. W ocenie sądu w sytuacji zagrożenia załamania całego systemu gospodarczego władze państwowe nie tylko są uprawnione, lecz wręcz zobligowane do podjęcia właściwych kroków prewencyjnych. W toku postępowania pozwany wykazał, że były to działania konieczne, natomiast strona powodowa nie przedstawiła przekonujących dowodów, że zamierzone cele można było osiagnąć w mniej ingerencyjny sposób ${ }^{18}$.

W kolejnych sprawach istotna rolę odegrały organy EOG, w tym przede wszystkim Urząd Nadzoru EFTA (ESA) i Trybunał EFTA ${ }^{19}$. Na gruncie działań restrukturyzacyjnych podjętych w stosunku do LBI powstał spór dotyczący zakresu pojęcia „depozyt”. Kwestia ta miała szczególne znacznie dla wierzycieli, gdyż w ramach podziału problemowego banku zdecydowano się na przeniesienie depozytów do nowo utworzonego podmiotu, który miał w założeniu przejąć i kontynuować zdrową część działalności poprzednika poddanego postępowaniu upadłościowemu. Na gruncie sprawy Aresbank S.A. przeciwko NBI $h f$., FME $i$ rzqdowi Islandii w drodze pytania prejudycjalnego zwrócono się o interpretacje przepisów dyrektywy 94/19/WE do Trybunału EFTA. W udzielonej odpowiedzi w sprawie E-17/11 Trybunał zwrócił uwagę, że na gruncie prawa unijnego dla zakresu definicji depozytu nie ma znaczenia charakter deponenta. Ma to jedynie wpływ na fakt objęcia danych należności systemem gwarantowania depozytów. Przychylono się do stanowiska zaprezentowanego w toku postępowania przez KE, wskazując na podwójne znaczenie depozytu na gruncie dyrektywy 94/19/WE - techniczne w ścisłym rozumieniu definicji zawartej $\mathrm{w}$ art. 1 ust. 1 oraz funkcjonalne wynikające $\mathrm{z}$ celu dyrektywy, jakim jest ochrona depozytów. Jednocześnie wskazano, że to sąd krajowy jest zobowiązany do ostatecznego zadecydowania o tym, jaki rodzaj definicji obowiązuje na gruncie prawa islandzkiego oraz jaki rodzaj definicji ma znaczenie dla rozpatrywanej sprawy ${ }^{20}$. Orzeczenie sądu niższej instancji $\mathrm{w}$ konsekwencji odmawiało problemowym wierzytelnościom statusu depozytu, jednocześnie opinia Trybunału EFTA oraz tożsamość definicji krajowej z defi-

\footnotetext{
18 Supreme Court Verdict No. 340/2011, Sąd Najwyższy Islandii, 28 października 2011 r., s. 24 i 30.

${ }^{19}$ Konsekwencje prawne wynikające z przynależności do EOG szeroko omawia M. E. Méndez-Pinedo, The Icesave dispute in the aftermath of the Icelandic financial crisis: revisiting the principles of state liability, prohibition of state aid and non-discrimination in European law, „European Journal of Risk Regulation” 2(3), 2011, s. 357-363.

${ }^{20}$ Judgement of the EFTA Court in Case E-17/11 - Aresbank S.A. vs. Landsbankinn hf., Fjármálaeftirlitid and Icelandic State, Trybunał EFTA, 22 listopada 2012 r., s. 19-20.
} 
nicją zawartą w dyrektywie 94/19/WE nie pozostawiały Sądowi Najwyższemu Islandii wiele swobody interpretacyjnej. W konsekwencji zdecydowano się na wyjątkowe rozwiązanie - podtrzymano wyrok sądu niższej instancji, jednocześnie opierając uzasadnienie na odmiennej argumentacji. W ocenie Sądu nadzorca krajowy w decyzji administracyjnej posłużył się terminem „depozyt” w oderwaniu od obowiązującej regulacji prawnej, a jego dookreślenie nastapiło $\mathrm{w}$ drodze kolejnych działań organu ${ }^{21}$. W ten sposób usankcjonowano posługiwanie się przez organ administracji terminologią pozostającą w izolacji od krajowych przepisów prawnych.

Również w ramach procedury pytania prejudycjalnego Trybunał EFTA został poproszony o wydanie opinii na temat zgodności obostrzeń kapitałowych z zasadą swobody przepływu kapitału, w szczególności zaś czy przedsięwzięte ograniczenia są zgodne z przepisami zawartymi w art. 43 par. 2 i 4 umowy o EOG dotyczącymi limitowania przepływów kapitałowych w związku z możliwością zaistnienia poważnych niebezpieczeństw dla krajowego rynku kapitałowego oraz bilansu płatniczego. W ocenie Trybunału EFTA wdrożone działania nie naruszają umowy EOG, w szczególności zaś pozostają w zgodzie z zasadą proporcjonalności oraz zachowują zasadę pewności obrotu prawnego. Podobnie jak we wcześniejszych przykładach, ich uzasadnieniem są szczególne okoliczności ekonomiczne, w tym przede wszystkim zagrożenie w postaci ryzyka destabilizacji kursu walutowego oraz polityki pieniężnej22. Warto zaznaczyć, że w 2010 r. Organ Nadzoru EFTA w ramach postępowania wyjaśniającego w związku ze skargami dotyczącymi naruszenia zasady swobody przepływu kapitału przez Islandię wydał decyzje odmawiajace wszczęcia postępowania przeciwko Islandii, uznając zasadność przedsięwziętych kroków ${ }^{23}$.

Niewątpliwie najszerszym echem odbiło się orzeczenie Trybunału EFTA w sprawie E-16/11, która dotyczyła odpowiedzialności z tytułu gwarantowania depozytów i była związana z niepowodzeniem wypłaty kwot gwarantowanych w stosunku do depozytów zgromadzonych w zagranicznych oddziałach restrukturyzowanego banku LBI. Przed kryzysem prowadził on działalność w Wielkiej Brytanii oraz Holandii, głównie w postaci oferowania atrakcyjnie oprocentowanych depozytów pod marką Icesave. Zgodnie z zasadami prowadzenie działalności bankowej w ramach EOG depozyty w oddziałach banków islandzkich pozostawały gwarantowane przez system gwarancyjny kraju pochodzenia ${ }^{24}$. Jednakże w sytuacji odmowy spełnienia roszczeń w celu unik-

${ }_{21}$ Judgement of the Supreme Court of Iceland No 169/2011, Sąd Najwyższy Islandii, 17 stycznia 2013 r., s. 10.

${ }_{22}$ Judgement of the EFTA Court in Case E-3/11 - Sigmarsson vs. the Central Bank of Iceland, Trybunał EFTA, 14 grudnia 2011 r., s. 12-13.

${ }^{23}$ Decision of the EFTA Surveillance Authority 501/10/COL, Organ Nadzoru EFTA, 15 grudnia $2010 \mathrm{r}$.

${ }^{24}$ W maju 2008 r. LBI podją decyzję o włączeniu swojego holenderskiego oddziału do systemu gwarantowania kraju goszczącego w celu wyrównania poziomu gwarancji do poziomu zapewnionego przez przepisy holenderskie. Analogiczne działania zostały podjęte w odniesieniu do oddziału zlokalizowanego w Wielkiej Brytanii. W efekcie środki zgromadzone w oddziałach zostały objęte zakresem gwarancji przez systemy krajów goszczących powyżej kwoty 20 tys. euro do wysokości 40 tys. euro i 50 tys. funtów. 
nięcia runu na banki Holendrzy i Brytyjczycy przejęli zobowiązania z tytułu gwarantowania depozytów. Rząd brytyjski zdecydował się na pełną wypłatę depozytów detalicznych. Z kolei rząd Holandii wypłacił środki wszystkim deponentom, ustalił jednak maksymalny poziom na 100 tys. euro.

W związku z zaistniała sytuacja ESA podją postępowanie wyjaśniające, którego efektem było skierowanie wniosku do Trybunału EFTA w sprawie naruszenie dyrektywy 94/19/WE, w szczególności zaś niewypełnienia zobowiązań wynikających z art. 3, 4, 7 i 10 przedmiotowej dyrektywy. Zagadnieniem spornym był charakter odpowiedzialności państw członkowskich za gwarantowanie depozytów - czy wiązał on co do rezultatu, czy też miał charakter odpowiedniego, starannego działania. W ocenie wnioskodawcy ESA, wspieranego przez KE, dyrektywa obligowała kraje członkowskie do wypłaty kwoty depozytów gwarantowanych niezależnie od okoliczności gospodarczych towarzyszacych temu zdarzeniu. Przy czym dyrektywa nie precyzuje konkretnych rozwiązań instytucjonalnych, pozostawiając szczegółowe rozwiązania, w tym w szczególności dotyczące właściwego finansowania (w tym pomocy państwa), w kompetencji państw członkowskich. Władze Islandii skoncentrowały swoja obronę na dwóch głównych wątkach. W ich ocenie przedmiotowa dyrektywa obliguje państwa członkowskie do wprowadzenia systemu gwarantowania spełniającego wymogi prawa europejskiego, a nie skutecznego wypłacenia środków gwarantowanych niezależnie od okoliczności. Drugim argumentem była skala zapaści sektora bankowego oraz utrata potencjalnych źródeł finansowania, co uniemożliwiało jakąkolwiek bezpośrednia pomoc państwa. W orzeczeniu wydanym 28 stycznia 2013 r. Trybunał EFTA przychylił się do stanowiska Islandii, w szczególności nie znalazł on w tekście dyrektywy 94/19/WE argumentów przemawiających za teza, że zobowiązuje ona państwa członkowskie do wsparcia finansowego systemu gwarantowania depozytów, zwłaszcza w przypadku kryzysów bankowych o charakterze systemowym. W konsekwencji zakres odpowiedzialności powinien być ograniczony do utworzenia efektywnego systemu gwarantowania, finansowanego składkami sektora bankowego, który w związku z powyższym nie może zakładać skrajnie negatywnego scenariusza. W związku z powyższym Trybunał nie dopatrzył się naruszenia przepisów dyrektywy ${ }^{25}$.

\section{Cypr - zarys działań antykryzysowych i kluczowe orzeczenia}

Sytuacja Cypru, mimo licznych analogii, znacząco odbiegała od modelu działań przyjętych przez rząd islandzki głównie z powodu różnic wynikających z faktu przynależności do UE, a przede wszystkim do strefy euro. Kondycja cypryjskiego sektora bankowego ulegała stopniowemu pogorszeniu od 2008 r., jednakże skutki krytyczne przyniosła restrukturyzacja w 2011 r. greckiego zadłużenia. W marcu 2013 r. konieczne okazało się podjęcie drastycznych kroków wobec dwóch największych banków (Laiki i Bank

${ }^{25}$ Judgement of the EFTA Court in Case E-16/11 EFTA - Surveillance Authority vs. Iceland (Icesave), Trybunał EFTA, 28 stycznia 2013 r., s. 23-25. 
of Cyprus - $\mathrm{BoC}^{26}$ ), które wymagały wsparcia finansowego w kwocie $17 \mathrm{mld}$ euro $^{27}$. Pierwsze porozumienie między przedstawicielami KE, EBC, MFW oraz władzami Cypru zostało zawarte 16 marca. Zakładało ono udzielenie pomocy finansowej w wysokości 10 mld euro i obwarowane było szeregiem dodatkowych warunków gospodarczych, jednakże najważniejszy punkt porozumienia dotyczył zgromadzenia przez Cypr brakującej sumy (7 mld euro) koniecznej do restrukturyzacji dwóch głównych banków. Założono, że zostanie ona zgromadzona w drodze umorzenia części depozytów. Miało ono wynosić $9,9 \%$ oraz $6,75 \%$ odpowiednio wobec depozytów niegwarantowanych (powyżej 100 tys. euro) oraz depozytów gwarantowanych. Nałożenie swoistego jednorazowego podatku na depozyty zgromadzone również w bankach niepotrzebujących pomocy, w tym w szczególności na depozyty gwarantowane, spotkało się z powszechna krytyką jako naruszenie zaufania wobec podstaw współczesnej bankowości. Parlament cypryjski 19 marca odrzucił porozumienie.

Jednocześnie 22 marca uchwalono ustawę 17(I)/2013 (ang. The Resolution of Credit and Other Institutions Law of 2013) oraz ustawę 12(I)/2013 (ang. The Enforcement of Restrictive Measures on Transactions in Case of Emergency Law of 2013). Stanowily one podstawy prawne do przygotowywanych działań naprawczych. Natomiast ustawa 12(I)/2013 dotyczyła możliwości wprowadzenia obostrzeń w zakresie przepływów kapitałowych. Prace nad drugim porozumieniem, które tym razem uzyskało akceptację parlamentu, udało się zakończyć 25 marca. Zachowany został poziom proponowanej pomocy finansowej, jednocześnie zdecydowano o przyszłości problemowych banków.

W stosunku do Laiki Bank postanowiono o jego podziale na dwa podmioty, z którego jeden został następnie połączony z dokapitalizowanym BoC. Cała operacja miała na celu wyodrębnienie i utrzymanie „zdrowych” obszarów działalności obu banków przy jednoczesnej sprzedaży części majątku oraz przeniesieniu problemowych aktywów i zobowiązań do podmiotu, który został poddany postępowaniu upadłościowemu ${ }^{28}$. Stosowne działania stanowiły decyzje banku centralnego w postaci dekretów, w szczególności zaś dwóch najważniejszych - dekret 103/2011 w stosunku do Laiki oraz dekret 104/2011 w stosunku do $\mathrm{BoC}^{29}$. Tym razem podejmowane działania nie odbiły się negatywnie na depozytach gwarantowanych. Jednakże oznaczało to poniesienie większych strat przez depozyty niegwarantowane. Ostatecznie skala redukcji wyniosła 47,5\% (konwersja na kapitał własny banku), dodatkowo kolejne 37,5\% zostało prze-

\footnotetext{
${ }^{26}$ Aktywa sektora bankowego na Cyprze w momencie kryzysu szacowano na 750\% PKB, z czego ponad połowa przypadała na dwa największe banki. A. Michaelides, Cyprus: from boom to bail-in, „Economic Policy” 29(80), 2014, s. 655.

${ }^{27}$ Szerzej zob. C. Stephanou, The banking system in Cyprus: time to rethink the business model?, „Cyprus Economic Policy Review” 5(2), 2011, s. 123-124 i 129.

${ }_{28}$ A. Apostolides, Beware of German gifts near elections: how Cyprus got here and why it is currently more out than in the Eurozone, „Capital Markets Law Journal” 8(3), 2013, s. 639-644.

${ }^{29}$ G. Z. Georgiou, Cyprus: the post-bailout battle, „Commercial Dispute Resolution” 4(4), 2013, s. $70-71$.
} 
kształcone w depozyty o 3 terminach zapadalności (6, 9 i 12 miesięcy) ${ }^{30}$. Pozostałe $15 \%$ depozytów mogło zostać wypłaconych, o ile nie stało to w sprzeczności z wprowadzonymi obostrzeniami dewizowymi.

W przypadku Cypru (głównie ze względu na ramy czasowe, ale także przyjętą linię orzecznicza) w porównaniu z Islandią dotychczasowy dorobek orzeczniczy jest znacznie mniejszy. Działania Banku Centralnego Cypru jako organu restrukturyzacji i uporządkowanej likwidacji wzbudziły gwałtowną reakcję wierzycieli, w tym deponentów banków Laiki oraz BoC. Najwięcej wątpliwości nagromadziło się wokół dwóch kluczowych dekretów 103/2011 i 104/2011. Strony poszkodowane ww. działaniami odwołały się, wnosząc o unieważnienie dekretów, jednakże uczyniły to w ramach procedury administracyjnej, co okazało się kluczowe dla końcowego rozstrzygnięcia. W orzeczeniu w sprawie nr 551/2013 z 7 czerwca 2013 r. Sąd Najwyższy Cypru przychylił się do stanowiska prezentowanego wcześniej $\mathrm{w}$ ramach postępowania przez prokuratora generalnego Cypru, stwierdzając, że przedmiotowe dekrety banku centralnego nie stanowią decyzji administracyjnych i jako takie nie moga podlegać rewizji $\mathrm{w}$ trybie przewidzianym dla tego typu aktów.

Biorac pod uwagę ich treść, należy stwierdzić, że nie regulują one relacji na linii państwo-obywatel, lecz dotyczą relacji bank-klient. W ocenie Sądu Najwyższego problemowe akty należy traktować jako swoiste działania zarządcze prowadzone przez Bank Centralny Cypru, ale w ramach przejętych kompetencji właściwych organów banku, które podlegają procedurze cywilnej, a nie administracyjnej. W konsekwencji konieczne jest przeprowadzenie właściwego postępowania cywilnego, w szczególności zaś powodowie muszą wykazać, że w wyniku prowadzonych działań restrukturyzacyjnych naruszone zostały postanowienia umowne, w konsekwencji czego ponieśli szkodę ${ }^{31}$. Ten sposób interpretacji ma istotne znaczenie dla prowadzonych postępowań. Szczególnie problematyczne może okazać się wykazanie szkody, które powinno opierać się na porównaniu faktycznej, obecnej sytuacji deponentów (wierzycieli) z hipotetyczną sytuacją przeprowadzenia upadłości dwóch banków. Konieczne również może okazać się zakończenie toczących się postępowań w celu uwzględnienia ewentualnych odzyskanych środków z majątku upadłego banku.

\section{POKRYZYSOWE RAMY PRAWNE - ZARYS REFORM NA GRUNCIE PRAWA UE}

Już w 2010 r. KE przedstawiła projekt nowej dyrektywy w sprawie systemów gwarancji depozytów (dyrektywa DGS). Jednakże wraz z rozwojem sytuacji gospodarczej podejmowane były kolejne inicjatywy legislacyjne. Z punktu widzenia bezpieczeństwa depozytów należy wskazać na projekt dy-

${ }^{30}$ G. A. Hardouvelis, Overcoming the crisis in Cyprus, 2014, Economy \& Markets Eurobank Research, s. 9-11.

${ }^{31}$ E. Christofi, K. Philippidou, Cyprus, w: J. Cotton (ed.), The Dispute Resolution Review, Law Business Research, London 2014, s. 175-176; G. Z. Georgiu, op. cit., s. 71-73. 
rektywy w sprawie restrukturyzacji i uporządkowanej likwidacji (dyrektywa BRRD) oraz propozycję tzw. unii bankowej. Liczne powiązania formalne i merytoryczne poszczególnych aktów oraz konieczność całego pakietu zmian spowodowały, że ostatecznie dyrektywy $\mathrm{DGS}^{32}$ oraz $\mathrm{BRRD}^{33}$ przyjęto dopiero w 2014 r., podobnie jak rozporządzenie SRM ${ }^{34}$ wprowadzające jednolity system restrukturyzacji i uporządkowanej likwidacji - w zakresie tego ostatniego istotne znaczenie odgrywa również „Umowa o przekazywaniu i uwspólnianiu składek na rzecz jednolitego funduszu restrukturyzacji i uporządkowanej likwidacji” 35 .

Przedstawienie szczegółowych rozwiązań dyrektyw DGS, BRRD oraz SRM zdecydowanie przekracza zakres niniejszego opracowania, jednakże warto zwrócić uwagę na ewentualną możliwość sięgnięcia w ramach działań restrukturyzacyjnych po środki klientów zgromadzone na depozytach bankowych.

Należy wskazać, że co do zasady dyrektywa DGS zachowuje szeroka definicję depozytu rozumianego jako należność wynikającą z wpłat pozostawionych na rachunku lub z sytuacji tymczasowych w ramach normalnych operacji bankowych, które instytucja kredytowa jest zobowiąana wypłacić zgodnie z obowiąującymi przepisami i postanowieniami umownymi (art. 2 pkt 3), wskazując jednocześnie katalog depozytów niepodlegających gwarancji (art. 5 ust. 1) oraz pozostawiając $\mathrm{w}$ tym zakresie mniej znaczące opcje narodowe (art. 5 ust. 2 i 3). Potwierdzony został obowiazzek utworzenia i urzędowego uznania na terytorium państwa członkowskiego jednego lub więcej systemów gwarancji depozytów (art. 4 ust. 1). Wskazano także, że instytucja kredytowa nie może przyjmować depozytów, jeżeli nie uczestniczy w systemie urzędowo uznanym w jej państwie członkowskim pochodzenia (art. 4 ust. 3). Utrzymano również poziom gwarancji w wysokości 100 tys. euro (art. 6 ust. 1) w odniesieniu do sumy depozytów każdego z deponentów w danej instytucji kredytowej. Wypłata środków gwarantowanych powinna nastapić w czasie 7 dni roboczych od dnia stwierdzenie niedostępności środków, jednakże pozostawiono państwom członkowskim możliwość skorzystania z okresów przejściowych - aż do 2024 r. (art. 8 ust. 1 i 2 ).

\footnotetext{
${ }^{32}$ Dyrektywa Parlamentu Europejskiego i Rady 2014/49/UE z 16 kwietnia 2014 r. w sprawie systemów gwarancji depozytów, Dz. Urz. UE L 173, s. 149.

${ }^{33}$ Dyrektywa Parlamentu Europejskiego i Rady 2014/59/UE z 15 maja 2014 r. ustanawiajaca ramy na potrzeby prowadzenia działań naprawczych oraz restrukturyzacji i uporządkowanej likwidacji w odniesieniu do instytucji kredytowych i firm inwestycyjnych oraz zmieniająca dyrektywę Rady 82/891/EWG i dyrektywy Parlamentu Europejskiego i Rady 2001/24/WE, 2002/47/WE, 2004/25/WE, 2005/56/WE, 2007/36/WE, 2011/35/UE, 2012/30/UE i 2013/36/EU oraz rozporządzenia Parlamentu Europejskiego i Rady (UE) nr 1093/2010 i (UE) nr 648/2012, Dz. Urz. UE L 173, s. 190.

${ }^{34}$ Rozporządzenie Parlamentu Europejskiego i Rady 806/2014 z 15 lipca 2014 r. ustanawiajace jednolite zasady i jednolitą procedurę restrukturyzacji i uporządkowanej likwidacji instytucji kredytowych i niektórych firm inwestycyjnych w ramach jednolitego mechanizmu restrukturyzacji i uporządkowanej likwidacji oraz jednolitego funduszu restrukturyzacji i uporządkowanej likwidacji oraz zmieniające rozporządzenie (UE) nr 1093/2010, Dz. Urz. UE L 225, s. 1.

${ }^{35}$ Zob. http://register.consilium.europa.eu/doc/srv?]=PL\&f=ST\%208457\%202014\%20INIT [dostęp: 12.06.2015].
} 
Z punktu widzenia bezpieczeństwa depozytów szczególne znaczenie należy przypisać regulacjom zawartym w art. 10 dotyczącym finansowania systemów gwarancji depozytów. Co do zasady poziom docelowy funduszu ma zostać osiagnięty w $2024 \mathrm{r}$. w drodze składek ex ante zebranych od sektora i wynosić $0,8 \%$ kwoty gwarantowanych depozytów wszystkich członków systemu gwarantowania, przy czym 30\% całkowitej kwoty dostępnych środków może być pokryte przez tzw. zobowiązania do zapłaty. Zgodnie z przepisami dyrektywy możliwe jest również wprowadzenie nadzwyczajnych składek ex post, ale w wysokości nieprzekraczającej 0,5\% gwarantowanych depozytów. Katalog źródeł finansowania należy określić jako otwarty, gdyż na podstawie art. 10 ust. 9 państwa członkowskie zapewniaja, by systemy gwarancji depozytów dysponowały odpowiednimi alternatywnymi mechanizmami finansowania, umożliwiającymi im pozyskanie krótkoterminowego finansowania $\mathrm{w}$ celu zaspokojenia wniesionych przeciwko nim roszczeń.

Istotne znaczenie maja również rozwiązania zawarte $\mathrm{w}$ dyrektywie BRRD. Na jej podstawie wprowadzono szeroki wachlarz narzędzi prawnych zarówno o charakterze prewencyjnym (np. plany naprawy - art. 5, plany restrukturyzacji i uporządkowanej likwidacji - art. 10), jak i w postaci władczych instrumentów o charakterze interwencyjnym (np. instrument zbycia działalności, instrument instytucji pomocowej, instrument wydzielenia aktywów, instrument umorzenia i konwersji długu - art. 37-58) ${ }^{36}$. Zabezpieczenie finansowe działań maja stanowić fundusze restrukturyzacji i uporządkowanej likwidacji gromadzące składki ex ante. W ciąu dziesięciu lat zebrane środki mają osiagnąć poziom 1\% depozytów gwarantowanych. Szczególne oczekiwania są jednak związane z narzędziem umorzenia i konwersji długu - art. 43-57 (ang. write down i bail-in). Z jego wykorzystaniem wierzytelności stanowić mają dodatkowy bufor absorpcji strat ponad podstawowe wymogi kapitałowe. Podmiotami obciążonymi będą nie tylko właściciele, ale również wierzyciele, a w szczególnych sytuacjach może to dotyczyć również deponentów (BRRD wyklucza z zakresu umorzenia i konwersji jedynie depozyty gwarantowane - czyli do wysokości 100 tys. euro). Jednakże depozyty osób fizycznych, mikroprzedsiębiorstw, małych i średnich przedsiębiorstw będą miały uprzywilejowaną pozycję w hierarchii wierzycieli banku, w efekcie będą uwzględniane w absorpcji w ostateczności, jeśli wcześniejsze umorzenia i konwersje okażą się niewystarczające (art. 44 ust. 2 w zw. z art. 48 i 108).

\footnotetext{
${ }^{36}$ Rozporządzenie SRM w dużej części pozostaje w funkcjonalnym związku z dyrektywą BRRD. W wielu aspektach przyjęto analogiczne rozwiązania, np. wczesna interwencja, plany restrukturyzacji, instrumenty interwencyjne, finansowanie oraz możliwość wykorzystania funduszu - por. odpowiednio art. 8, 13, 22-27, 67-75 oraz art. 76-79 SRM. Główne różnice dotyczą sfery instytucjonalnej i decyzyjnej, przy czym są one szczególnie ważkie w obszarze finansowania - co w głównej mierze wynika ze stopniowego „uwspólnotowienia” funduszu dla krajów uczestniczących w unii bankowej (art. 1 i 3-5 umowy o przekazywaniu i uwspólnianiu składek na rzecz jednolitego funduszu restrukturyzacji i uporządkowanej likwidacji).
} 


\section{PODSUMOWANIE}

Bezpieczeństwo depozytów pozostaje jednym z głównych celów regulacji sektora bankowego. Niemniej analizujac przytoczone akty prawne, trudno nie odnieść wrażenia, że ciężar problematyki bezpieczeństwa depozytów został przeniesiony z pierwotnej funkcji wypłaty depozytów gwarantowanych w kierunku działań prewencyjnych (w tym pomocowych), a w szczególności zaś działań o charakterze restrukturyzacyjnym, likwidacyjnym oraz upadłościowym. Skala i charakter współczesnej działalności bankowej sprawiaja, że sama wypłata depozytów będzie miała uzasadnienie głównie w przypadku małych i średnich banków, ustępując miejsca innym instrumentom w przypadku instytucji o znaczeniu systemowym.

Skuteczność nowych narzędzi prawnych jest w dużym stopniu uzależniona od uzyskania odpowiedniej wiarygodności finansowej, tj. zapewnienia właściwych źródeł finansowania. Kluczowe w tym zakresie poziom docelowy właściwych funduszy oraz termin ich osiagnięcia - napawaja pewnym sceptycyzmem. Natomiast duże nadzieje wiąże się z instrumentem umorzenia i konwersji długu. W tym zakresie należy podkreślić, że zachowano zasadę nienaruszalności depozytów gwarantowanych, co jednak nie wyklucza dokonania stosownych umorzeń ponad kwotę gwarancji. Z dzisiejszej perspektywy wydaje się, że nowe ramy prawne, które stanowią regulacje kolejnej generacji o dużym stopniu szczegółowości, stanowią jasne i precyzyjne granice możliwych działań. Jednakże jak pokazuja przytoczone przykłady Islandii i Cypru, kryzys bankowy stanowi istotne wyzwanie dla wymiaru sprawiedliwości zarówno pod względem proceduralnym, jak i merytorycznym. Poziom złożoności spraw przekłada się na ramy czasowe prowadzenia postępowań, a także na konieczność orzekania w oparciu o zasady prawne i ważenie szczególnych interesów, które niejednokrotnie stanowią wartości konstytucyjne. Oczekiwania i presja społeczna, a także wyjątkowość uwarunkowań gospodarczych sprawiaja, że można zauważyć duży margines wyrozumiałości sądownictwa w stosunku do wdrożonych działań.

mgr Piotr Fratczak

Uniwersytet Warszawski

piotr.fratczak@student.uw.edu.pl

\section{SAFETY OF BANK DEPOSITS IN LIGHT OF ICELANDIC AND CYPRIOT FINANCIAL CRISIS EXPERIENCE - REGULATORY ASPECTS}

\section{Summary}

The main aim of the article is to analyse the safety of bank deposits both from the theoretical and practical perspective. Deposit guarantee schemes constitute an important part of the banking regulation. Deposit insurance is one of the instruments of crisis management. The starting point of the analysis is a brief description of the main regulatory themes relating to deposit insurance. The central part of this article focuses on anti-crisis measures undertaken by Iceland and Cyprus - two countries where the banking crisis reached an exceptional scale becoming the direct cause of a gross violation of the rights of depositors. A significant emphasis has been placed on the legal issues arising from the decisions of the competent authorities, which were subsequently reviewed by appropriate courts of justice. The key issues relating to the deposit guarantee schemes have been raised in the analysis of legislative reforms undertaken at the EU level. 
